\title{
Direct land/sea correlation of the Eemian, and its comparison with the Holocene: a high-resolution palynological record off the Iberian margin
}

\author{
M.F. Sánchez Goñi ${ }^{1,2}$, J.-L. Turon ${ }^{1}$, F. Eynaud ${ }^{1}$, N.J. Shackleton ${ }^{3} \&$ \\ O. Cayre ${ }^{4}$ \\ 1 Département de Géologie et Océanographie, UMR-CNRS 5805, Université Bordeaux I, \\ Avenue des Facultés, 33405 TALENCE, France \\ 2 Instituto de Ciencias de la Tierra 'Jaume Almera', CSIC, Lluís Solé i Sabarís s/n, \\ 08028 BARCELONA, Spain \\ ${ }^{3}$ Godwin Institute for Quaternary Research, Department of Earth Sciences, Godwin \\ Laboratory, Pembroke Street, CAMBRIDGE CB2 3SA, UK \\ 4 CNRS-CEREGE, BP 80, 13545 AIX-EN-PROVENCE Cx 4, France
}

Received: 12 November 1998; accepted in revised form: 12 February 2000

\begin{abstract}
High-resolution pollen, dinocyst and isotopic profiles covering the marine isotope stage 5 (MIS 5) are presented from core MD952042 (Tagus abyssal plain, $37^{\circ} 47^{\prime} \mathrm{N}, 10^{\circ} 09^{\prime} \mathrm{W}$ ). Both marine and terrestrial proxies indicate the occurrence of a Bølling-Allerød-Younger Dryas-like event at the beginning of MI substage 5e. The terrestrial Eemian stage coincides with both the lightest oxygen isotope values of substage $5 \mathrm{e}$ and the heavier ones approaching the $5 \mathrm{e} / 5 \mathrm{~d}$ transition. Accordingly, the Eemian is not equivalent to MI substage 5e, as the Holocene is not equivalent to MIS 1.

Remarkably, both pollen and dinocyst data reflect the same climatic pattern on land and ocean, and they evidence a succession of climatic events that the isotope signal does not identify. The Eemian began with a Mediterranean vegetation that was gradually replaced by Eurosiberian formations indicating a change from Mediterranean to oceanic climates. In the middle of the Eemian, warming conditions were interrupted by an event corresponding to a slight cooling resulting from an increase in precipitation over land and ocean. Finally, a warming trend characterised the last phase of the Eemian. The occurrence of small climatic changes during this interglacial is inconsistent with the dramatic variability suggested by the GRIP ice-core record.
\end{abstract}

Keywords: climate, dinocysts, Eemian, North Atlantic, marine isotope substage 5e, planktonic isotopes, pollen, southwestern Europe, vegetation

\section{Introduction}

The duration and the suggested climatic instability of the Eemian interglacial is a current topic of debate (Dansgaard et al., 1993; GRIP, 1993; Field et al., 1994; Thouveny et al., 1994; Tzedakis et al., 1994; Kukla et al., 1997; Seidenkrantz \& Knudsen, 1997). Indirect correlations between pollen successions and MIS $5 \mathrm{e}$ have led to the Eemian being given different time spans that vary between 23,000 and 12,000 years (128-112 ka BP; $127-115 \mathrm{ka} \mathrm{BP} ; 130-107 \mathrm{ka}$ BP) (e.g., Woillard \& Mook, 1982; Guiot et al., 1989; De Beaulieu \& Reille, 1992; Pons et al., 1992). Turon (1984a), relying on a direct land/sea correlation from a low-resolution marine pollen record (SU8132), also proposed that MIS $5 \mathrm{e}$ is the marine equivalent to the continental Eemian. Other authors (Field et al., 1994) estimated, based on pollen successions from annually laminated sediments, that the Eemian lasted 11,000 years. Some others (Kukla et al., 1997; Broecker, 1998) have suggested that the Eemian lasted from the beginning of MIS 5e to the second part of MIS 5d, i.e., 22,000 years, based on an indirect correlation between North Atlantic sediment cores and the La Grande Pile pollen record.

Excluding the problematic GRIP ice-core signal 
(Alley, 1995), ocean and terrestrial high-resolution records from the North Atlantic region reveal different degrees of variability concerning the number and/or the amplitude of the climatic changes. Isotope and pollen records from middle latitudes suggest a quite stable period (Pons et al., 1992; Cortijo et al., 1994; Adkins et al., 1997), whereas records from the high latitudes reflect more than one cold event during the Eemian (Fronval \& Jansen, 1997; Seidenkrantz \& Knudsen, 1997). Two hypotheses have been proposed to explain the difficulty of identifying Eemian climatic changes at middle latitudes (Fronval \& Jansen, 1997): the failure of most transfer functions to detect interglacial fluctuations and the damping of the high-latitude climatic oscillations at lower latitudes. In contrast, other studies on cores from the subpolar North Atlantic account for weak amplitude fluctuations (1$2{ }^{\circ} \mathrm{C}$ ) at high latitudes during the Eemian (Oppo et al., 1997). Moreover, some authors have proposed changes in the thermohaline circulation as the mechanism involved in the intensity of the climatic variability during this interglacial (Cortijo et al., 1994; Weaver \& Hughes, 1994).

In order to discuss how long and how stable the Eemian climate was, we need to emphasise that this interglacial has been generally considered as the equivalent of the OI substage 5e (e.g., Pons et al., 1992; Oppo et al., 1997; Fronval et al., 1998; Maslin et al., 1998), in spite of the lack of a detailed direct land/sea correlation between marine and terrestrial stratigraphies. Consequently, the Eemian has became synonymous with OI substage $5 \mathrm{e}$ and is vaguely referred to as the 'last interglacial'. Bearing this in mind, the main goal of the present contribution is to make a comparison between pollen, dinocyst and isotopic profiles from ocean sediment core MD952042. This allows, for the first time, the establishment of detailed, direct land/sea correlation between marine and terrestrial stratigraphies and between the European terrestrial climate and the North Atlantic environments. To this end, we used proxy data from pollen-rich high-resolution marine sediment (core MD952042) from the southwestern margin of the Iberian Peninsula. This pollen record also provides the first continuous detailed reflection of the vegetation history of southwestern Europe for the last interglacial complex and particularly for the Eemian.

\section{Environmental setting}

Core MD952042 was collected from the south-western margin of the Iberian Peninsula $\left(37^{\circ} 47^{\prime} \mathrm{N}\right.$, $10^{\circ} 09^{\prime} \mathrm{W}$ ) in the Tagus abyssal plain at $3146 \mathrm{~m}$ water depth on the pathway of the Canary Current. At pre- sent, this area (Fig. 1) is characterised by a seasonal coastal upwelling during summer (Fiúza et al., 1982). Core MD952042 is from a region with a high sedimentation rate and has very good preservation of both pollen and dinocyst assemblages.

The fact that the dominant winds in this area come from the north-western Atlantic Ocean, suggests, together with experimental studies (Heusser, 1985), that the pollen preserved in this core is mainly supplied by rivers. The pollen is particularly derived from the Tagus river, which crosses the centre of the Iberian Peninsula. Nowadays, the Tagus basin is dominated by a Mediterranean climate, with mild winters (winter minimum: +5 to $-1{ }^{\circ} \mathrm{C}$; winter maximum: +13 to $+8^{\circ} \mathrm{C}$ ) and hot and dry summers; there is an important oceanic component in its western zone (Pagney, 1976; Peinado Lorca \& Martínez-Parras, 1987). Pollen preserved in core MD952042 comes therefore from a transitional vegetational zone: Atlantic floristic elements (Quercus pyrenaica and Q. faginea) in the north and west and Mediterranean flora (Quercus rotundifolia, $Q$. suber, Funiperus thurifera and Pinus sylvestris) to the south and east (Blanco Castro et al., 1997) (Fig. 1). Mediterranean shrub vegetation represented by Cistus is replaced by Ericaceae in the wettest zones (Peinado Lorca \& Martínez-Parras, 1987). Shifts between Mediterranean and Atlantic vegetation in the pollen record therefore reflect past variations in temperature and precipitation.

\section{Material and methods}

Core MD952042 was collected with a giant corer by the Marion Dufresne oceanographic ship, under the auspices of the IMAGES programme (IMAGES I, 1995) (Bassinot \& Labeyrie, 1996). The core is 3956 $\mathrm{cm}$ long and is composed of hemipelagic clay. The last interglacial complex is represented by $7 \mathrm{~m}$ of sediment. Its isotope stratigraphy was established by Cayre (1997) using the planktonic foraminiferan Globigerina bulloides and dated by comparison with the SPECMAP 'stack' (Martinson et al., 1987). The core was sampled for pollen and dinocysts analyses at 10 $\mathrm{cm}$ intervals and between 4 and $1 \mathrm{~cm}$ in the most significant parts, such as Termination II. The temporal resolution varies between 100 and 1000 years.

The preparation technique for pollen and dinocysts followed the procedure described by De Vernal et al. (1996) (for details: see Sánchez Goñi et al., 1999). A minimum of 100 pollen grains, excluding Pinus and spores, and a minimum of 20 taxa were counted in each of the 107 samples analysed. Pinus was excluded from the sums because of its well known over-representation in marine deposits (Heusser \& Balsam, 


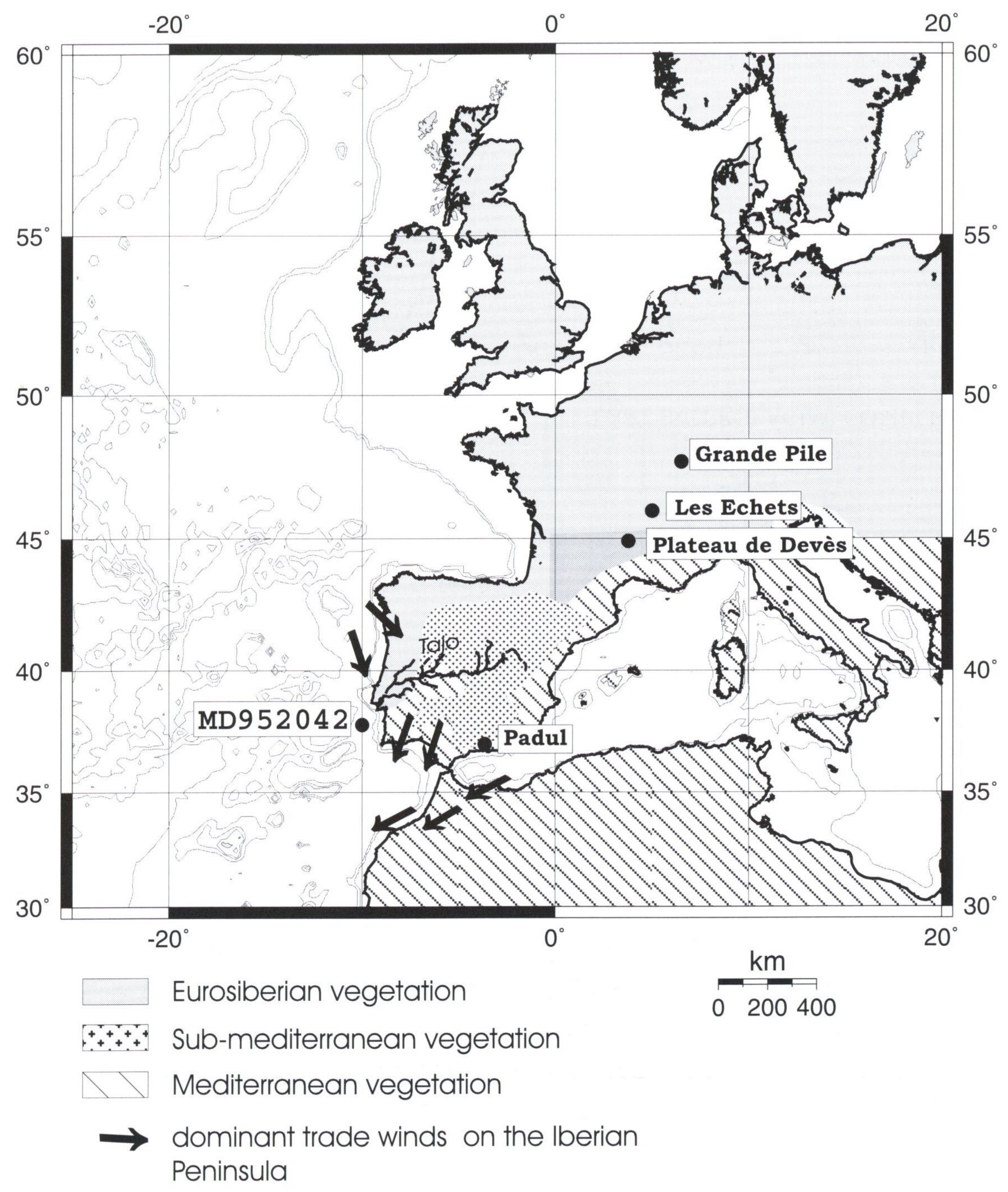

Fig. 1. Location map. The infilled circles indicate the position of core MD952042 (37 $48^{\prime} \mathrm{N} ; 10^{\circ} 10^{\prime} \mathrm{W} ; 3148$ $\mathrm{m}$ water depth) and the nearest European cores, mentioned in the text. The arrows indicate the direction of the dominant winds on the Iberian peninsula.The distribution of the modern vegetation follows Walter (1954) in Blanco Castro et al. (1997).

1977). The pollen percentages for terrestrial taxa are based on a main pollen sum that excludes Pinus, spores, indeterminable and unknown types. Pinus percentages are calculated from the main sum plus Pinus. The percentages of spores were estimated from the total sum (pollen + spores + indeterminables + unknowns). An average of 300 dinoflagellate cysts were identified and examined from each sample. The identifications of dinoflagellate cysts are based on studies by Turon (1984b) and De Vernal et al. (1992), and the terminology follows the Lentin \& Williams (1989) index.

\section{Results and discussion}

A total of 82 taxa with a concentration of grains varying between 898 and 21,722 grains per $\mathrm{cm}^{3}$ were identified in the pollen analysis. The pollen diagram from core MD952042 is shown in Figure 2; this figure shows only selected taxa, together with the planktonic isotope stratigraphy from the same core. Fifteen pollen zones were identified using the definition sys- tem of Gordon\& Birks (1980) and were assigned independently of the marine isotope stratigraphy. These zones, numbered from bottom to top and prefixed by the abbreviated site name MD42, have been correlated with the stratigraphical units from western European pollen successions (Woillard, 1978; De Beaulieu \& Reille, 1984; Follieri et al., 1988; Pons \& Reille, 1988; Pons et al., 1992). Interpretations of past vegetation and climates are based on the indicator-species approach (Birks \& Birks, 1980).

At the base of the succession, a cold and dry period is reflected by the high percentages of steppic and Cupressaceae pollen; it is correlated with the penultimate glacial (Saalian). After this, the increase in the percentages of Betula, deciduous and evergreen Quercus and Ericaceae suggests warming and wetter conditions. This relatively warm and wet period was interrupted by a short cooling and drying phase, possibly analogous to the Younger Dryas, reflected by a decrease in deciduous Quercus and Ericaceae pollen percentages. The Eemian is characterised in this succession by the development of Mediterranean taxa 


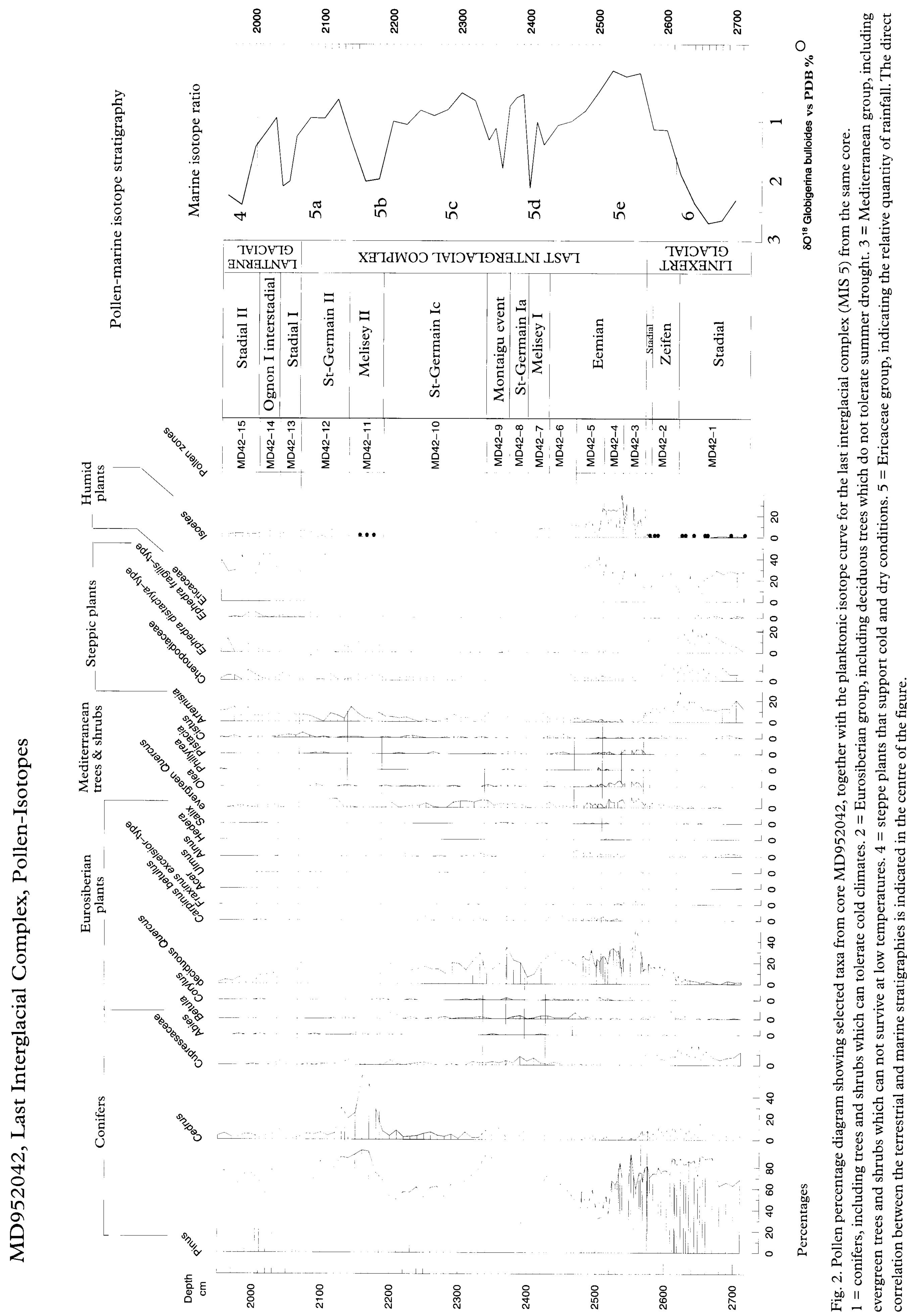




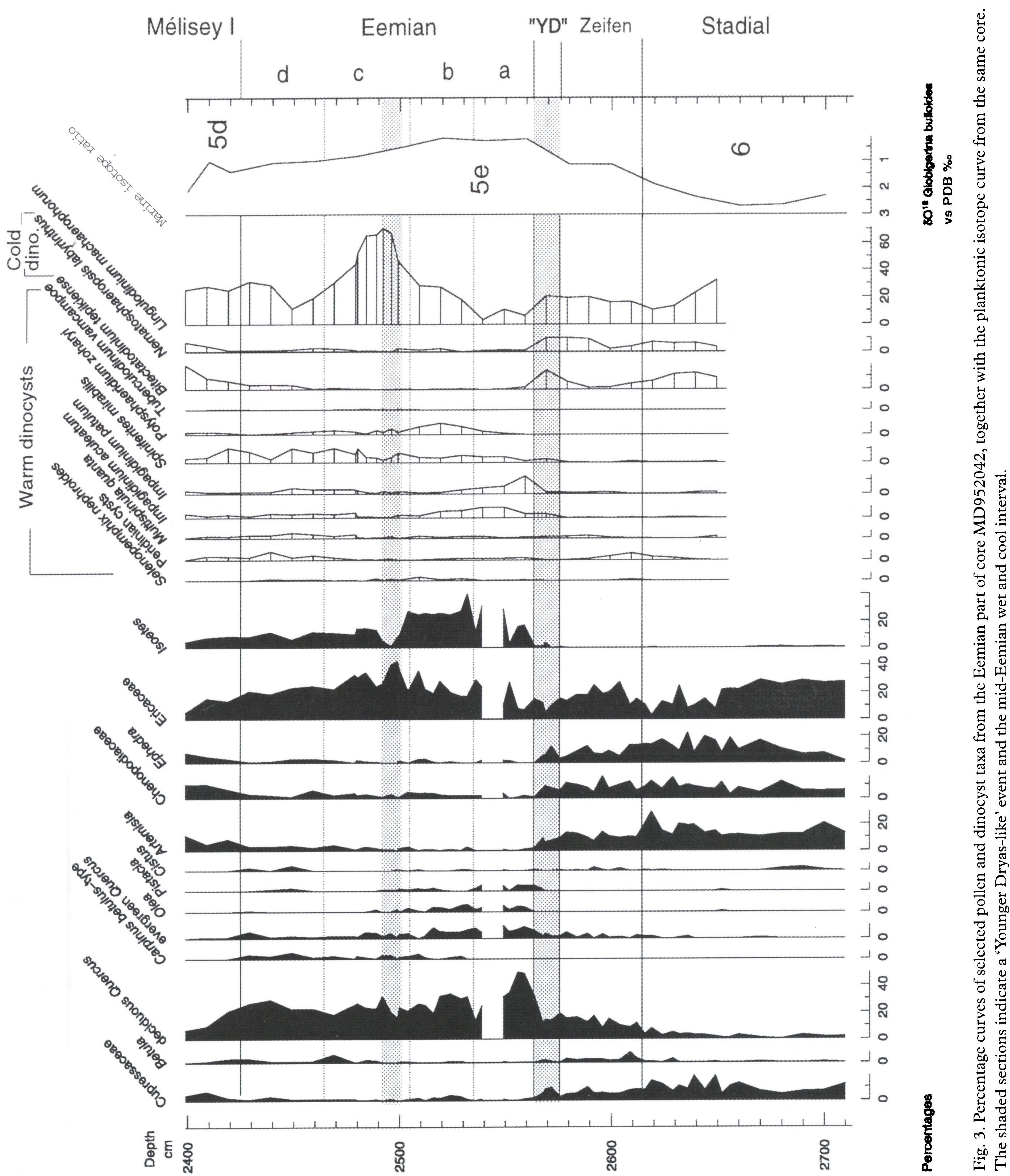

and Carpinus betulus-type trees. In the lower part of the Eemian profile, there is a pollen hiatus covering $10 \mathrm{~cm}$ due to the very low pollen concentrations in this zone. No difference in the percentages is observed on either side of this hiatus, however, suggesting that no vegetation change took place at the time. After the Eemian, cold and dry conditions were es- tablished again as indicated by the increase of steppic pollen and by the decrease of tree-pollen frequencies. This cold phase is correlated with the Early Weichselian Mélisey I stadial. A succession of cold and warm phases characterises the top of the succession; the phases are correlated with the St-Germain Ia interstadial, the Montaigu cold event, the St-Germain 
Ic interstadial, the Mélisey II stadial, the St-Germain II interstadial, the stadial I of the Lanterne (last) glaciation, the Ognon I interstadial, and stadial II of the Middle Weichselian, respectively (Sánchez Goñi et al., 1999).

\section{Direct land/sea stratigraphical correlation}

Detailed direct land/sea correlation in core MD952042 brings to light an interesting feature. The Eemian corresponds to the lightest-isotope values of MI substage $5 \mathrm{e}$ and to the heavier-isotope values towards the $5 \mathrm{e} / 5 \mathrm{~d}$ transition. In fact, the beginning of MI substage 5e, estimated with the planktonic foraminifera isotopic curve, includes at first a warmer and wetter climate - suggested by the gradual increase of the forest cover and Ericaceae - and then a short cooler and dryer phase indicated by the stagnation of the arboreal development and the decrease of Ericaceae (Fig. 3). The presence of this short cold period is confirmed by the dinocyst analysis (Fig. 3), since dinocysts indicate at the same moment an increase from 0 to $15 \%$ in the species associated to cold waters (Bitectatodinium tepikiense and Nematosphaeropsis labyrinthus).

Considering this period as analogous to the Younger Dryas cold event before the Holocene warming, the Eemian would start with the lightest-isotope values of MI substage 5e. This cold event has already been identified in several more northerly marine cores (Sarnthein \& Tiedemann, 1990; Seidenkrantz, 1993; Oppo et al., 1997; Fronval et al., 1998).

\section{The Eemian/Holocene comparison}

The hypothesis that the beginning of the Eemian coincides with the lightest-isotope values of MI substage 5e also seems to be confirmed by a detailed comparison (Fig. 4) of our results with the Late Glacial to Holocene succession in core SU8118 from the same site $\left(37^{\circ} 46^{\prime} \mathrm{N}, 10^{\circ} 11^{\prime} \mathrm{W}\right)$ and precisely dated by 28 corrected AMS dates ( Turon et al., 1995; Lézine \& Denèfle, 1997). The vegetation succession in the two cores displays an extraordinary similarity since in both cores the beginning of the interglacial is characterised by a decrease in Betula, a maximum of deciduous Quercus, a maximum of Mediterranean taxa, an abrupt decrease in steppics, a new increase of Ericaceae, and a maximum of Isoetes fern percentages. Furthermore, the first three Eemian pollen zones (MD42-3, MD42-4, MD42-5; climatic phases a, b and c) are quite similar to those of the Holocene (phases a', b' and c') (Fig. 4).

On the basis of this comparison, and applying the
Holocene model to the Eemian and vice versa, two relevant observations can be made. Firstly, the evidence from core MD952042 allows the first direct dating of the beginning of the Eemian, which should be fixed at around $126 \mathrm{ka} \mathrm{BP}$. The lack of benthic isotopic measurements makes it difficult to identify the $5 \mathrm{e} / 5 \mathrm{~d}$ substage boundary. The end of the Eemian has consequently not been dated as yet (work is in progress). Secondly, the last phase of the Eemian was characterised by a warming trend that lasted at least 3,000 years (Figs. 3 and 4, phase d).

\section{Climatic variability during the Eemian}

The Eemian in core MD952042 is characterised by four climatic phases (Figs.3 and 4, phases a to d). Mediterranean conditions (phase a), with mild winters and hot and dry summers - reflected by the maximum percentages of evergreen Quercus, Olea and Pistacia - changed to a temperate oceanic climate (phase b) indicated by the first record of Carpinus betulus-type and the increase of Ericaceae. An increase in precipitation, involving a cooling event (phase c), followed, reflected by the maximum of Ericaceae and the decrease of Mediterranean taxa and deciduous Quercus percentages. These wet and cool conditions, centred at around $119 \mathrm{ka} \mathrm{BP}$, reached their maximum over 400 years. This climate was replaced by temperate oceanic conditions (phase d), as indicated by an increase of deciduous Quercus and Mediterranean taxa percentages.

The climatic changes suggested by the pollen record are gradual and of small amplitude, lasting between 2,000 and 4,000 years. It is important to note that these results are in contradiction with the abrupt Eemian climatic changes suggested by the GRIP icecore record (Dansgaard et al., 1993; GRIP, 1993), by the transfer functions from the Bispingen (Germany) pollen succession (Field et al., 1994) and by the magnetic-susceptibility measurements of the Lac de Bouchet (France) succession (Thouveny et al., 1994). In our view, the high amplitude of the climatic changes suggested by these records (interglacial/ glacial shifts of $10^{\circ} \mathrm{C}$ ) would have been detected in core MD952042, the palynological study of which clearly indicates climatic changes of such amplitude. In fact, the climatic signal from the deepest part of the GRIP core has been questioned and explained as a result from an ice-flow phenomenon (Alley, 1995). The abrupt Eemian climatic variability suggested by the estimated temperatures on the German record has also been questioned (Aaby \& Tauber, 1995). Furthermore, recent palaeobotanical and oxygen-isotope results from three sites in central Germany (Litt 


\section{SU8118}

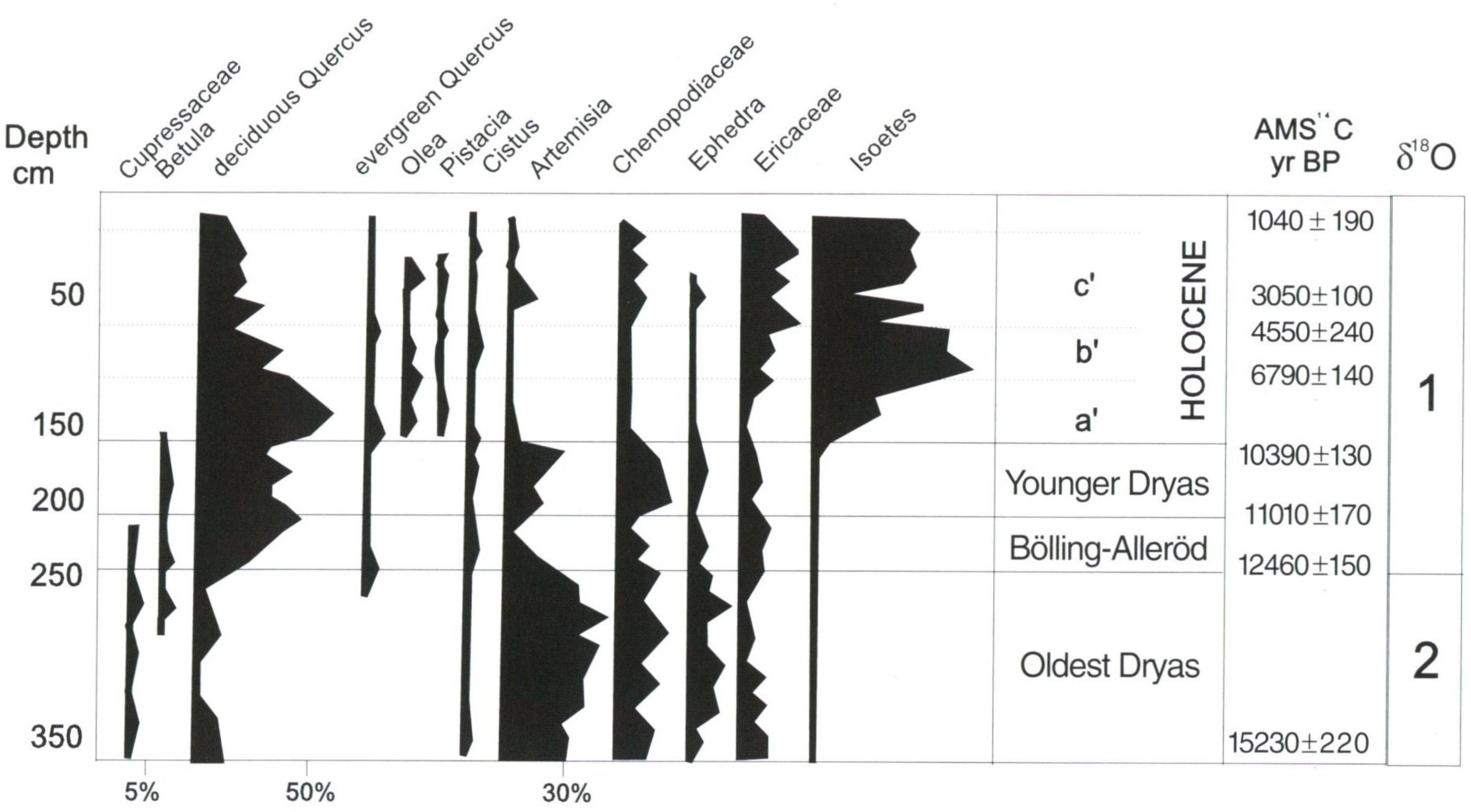

\section{MD952042}

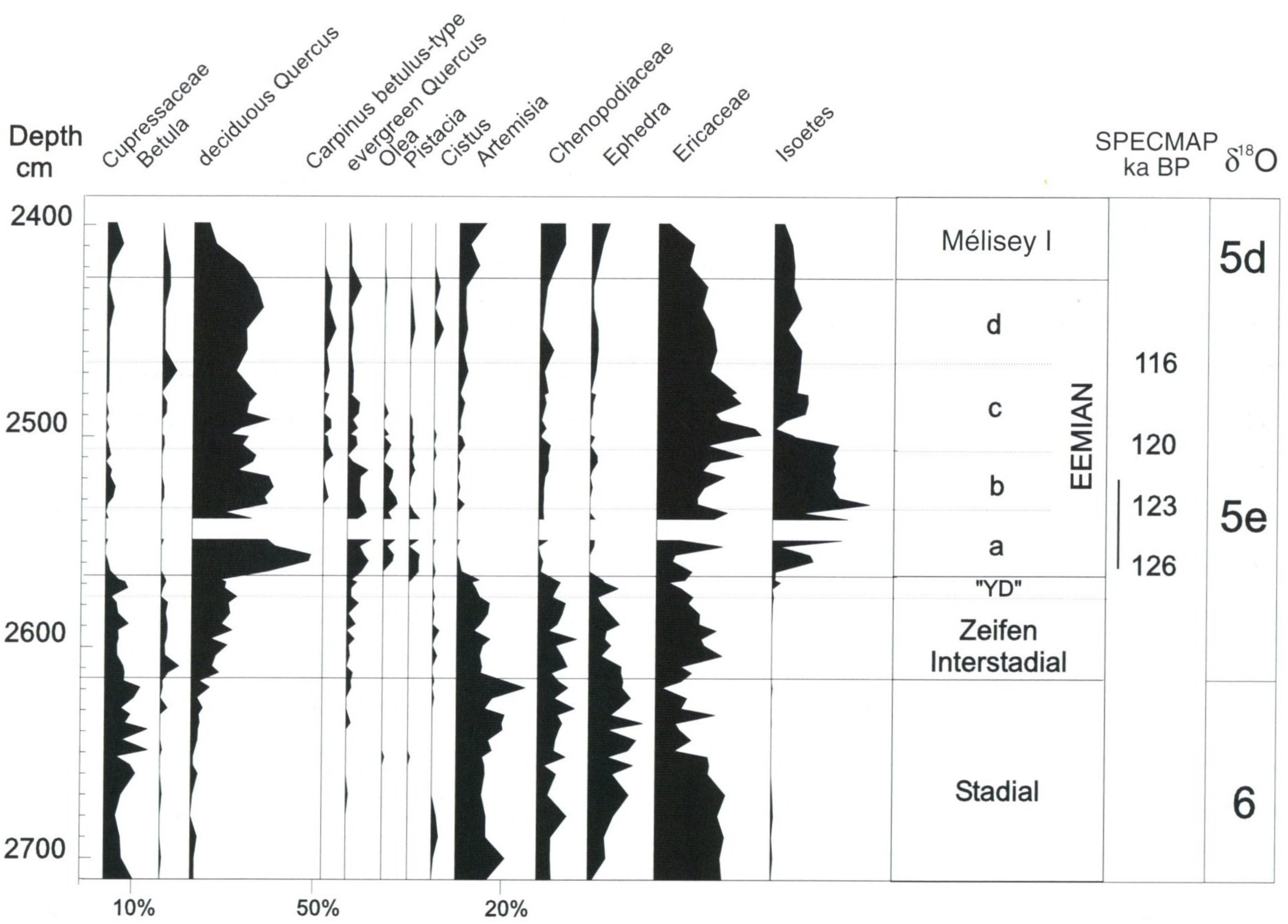

Fig. 4. Pollen records.

Top: the pollen record of selected taxa from the Late Glacial to Holocene interval (end of OI stage 2 and OI stage 1) of core $\mathrm{SU} 8118\left(37^{\circ} 46^{\prime} \mathrm{N}, 10^{\circ} 11^{\prime} \mathrm{W}\right.$; $3135 \mathrm{~m}$ water depth).

Bottom: the pollen record of selected taxa from the penultimate glacial (Saalian) to Eemian part (end of OI stage 6 and OI substage 5e) of core MD952042 (37 $47^{\prime} \mathrm{N}, 10^{\circ} 09^{\prime} \mathrm{W} ; 3146$ $m$ water depth). The solid line interval shows the lightest-oxygen isotopic values during the Eemian. et al., 1996) and the quantitative climatic reconstructions from seven European pollen records (Cheddadi et al., 1998) indicate that the Eemian was characterised by a relatively stable climate.

There is a remarkable difference when we compare the MD952042 record and other southern European successions (Follieri et al., 1988; Hooghiemstra et al., 1992; Cheddadi \& Rossignol-Strick, 1995) to the northernmost European pollen successions. Southern records are characterised by a Mediterranean climate (thermal optimum) in the early Eemian, followed by a freshening and humid period and ending with a warming trend. In contrast, the more northerly pollen successions (Zagwijn, 1961, 1996; De Beaulieu \& Reille, 1984, 1992; Guiot et al., 1989; Pons et al.,
1992) suggest a maximum forest development in the middle of the Eemian, based on the maximum development of Corylus and Carpinus betulus-type and thus a climatic optimum at the moment. Considering that the maxima in mean annual and summer insolations occurred during the very early Eemian (approx. 126 ka BP) (Berger \& Loutre, 1991), this north/south difference in the time of the maximum development of forest cover could reflect the time lapse that temperate trees took to reach northern European regions from their southern refugial zones.

Correlation between the pollen and dinocyst evidence demonstrates that European climatic changes were in phase with variations in sea-surface conditions during the Eemian (Fig. 3). For example, the 
Eemian thermal optimum - reflected by the maximum development of Quercus and Mediterranean forest (phases a and b) - is contemporaneous with the sea-surface temperature (SST) optimum indicated by the maximum percentages in warm dinocyst species such as Impagidinium aculeatum, I. patulum, Spiniferites mirabilis and Polysphaeridium zohary. In the middle of the Eemian, the increase of rainfall associated with a freshening (phase c) - suggested by the decrease of tree taxa and the maximum development of Ericaceae - coincided with a period of stratified waters indicated by the peak of Lingulodinium machaerophorum. The latter may reflect an input of fresh water as a result of an increase in precipitation over the ocean (Sánchez Goñi et al., 1999). This increase in precipitation over land and sea was linked with a gradual reduction of mean annual and summer insolation (Berger \& Loutre, 1991). This wet and relatively cold climate centred at 119 ka can be explained by a southward displacement of the polar front during this interval. It could be correlated with the midEemian cooling suggested by cores from the Norwegian (Cortijo et al., 1994) and northern seas (Seidenkrantz \& Knudsen, 1997) and from the subtropical Atlantic Ocean (Maslin \& Tzedakis, 1996; Maslin et al., 1998). In the Norwegian Sea and the subtropical Atlantic, this event lasted over 400 years and is dated between 123 and $122 \mathrm{ka}$. Cortijo et al. (1994) have suggested that this cooling was a result of a reduction in thermohaline circulation, both strengthening and enhancing the SST gradients between the Norwegian Sea and the North Atlantic. This phenomenon produced major atmospheric depressions bringing snow and promoting ice growth over the continental high latitudes (Cortijo et al., 1994). The gradual transition from a Mediterranean to a cool oceanic climate between 123 and $116 \mathrm{ka}$ in European low latitudes, as reflected by this core, implies an enlargement of the cyclonic zone towards the south in the middle of the Eemian.

\section{Conclusions}

High-resolution palynological analysis of core MD952042 suggests a Bølling-Allerød-Younger Dryas-like event at the beginning of OI substage $5 \mathrm{e}$ at the mid-latitudes of the North Atlantic region. This twostep deglaciation event at the beginning of substage $5 \mathrm{e}$, already identified in the high-latitude North Atlantic seems therefore to be of regional character. Pollen evidence also indicates that the Eemian expanded from the lightest isotope values of 5e (approx. $126 \mathrm{ka} \mathrm{BP}$ ) to the heavier-isotope values towards the $5 \mathrm{e} / 5 \mathrm{~d}$ transition. The Eemian is consequently not the exact time-equivalent of MI substage $5 \mathrm{e}$. Our conclusion contrasts with those of previous authors based on indirect correlations between terrestrial and marine records (see, among others, Woillard \& Mook, 1982; Pons et al., 1992; Kukla et al., 1997). It also differs from that based on a direct land/sea correlation from the low-resolution marine pollen record (Turon, 1984).

Concerning the climatic variability, four climatic phases of low amplitude are suggested by the MD952042 pollen analysis. This climatic variability on the continent was in phase with changes in seasurface conditions. These results are not consistent with the abrupt, high amplitude of the Eemian climatic changes suggested by the GRIP ice-core record and the continental successions at Bispingen (Germany) and Lac du Bouchet (France). In the middle of the Eemian, warming conditions were interrupted by an event (centred at around $119 \mathrm{ka} \mathrm{BP}$ ) characterised by an increase in precipitation and a slight cooling over both land and sea. The contemporaneous decrease in mean annual and summer insolation could have resulted in a cooling effect over the high latitudes and a reduction of the North Atlantic thermohaline circulation. This, in turn, could have promoted ice-growth at high latitudes, a southward displacement of the polar front and, therefore, an increase in precipitation as far as south-western Europe.

Finally, it is worth noting that the proxy approach applied to core MD952042, involving micropaleontological indicators, has indicated several climatic phases during the Eemian that would have been difficult to establish merely on the basis of isotope data. Pollen and dinocyst results have also been crucial in the identification of the mechanisms which determine the climatic change.

\section{Acknowledgements}

The core was recovered during the IMAGES I cruise. The Institut Français pour la Recherche Technologique et Polaire (IFRTP) provided financial support as well as NERC GR9/1648'A'. Funding for M.F. Sanchez Goñi was provided by the Spanish Ministry of Education and Science (attaching contract to the project $\mathrm{n}^{\circ}$ CL195-1905-C03-01). We also acknowledge EC contract ENV4-CT95-0131, French PNEDC, French MENRT and CNRS/INSU. We would like to thank $\mathrm{E}$. Vincent for sampling core MD952042 for palynological analysis and M.-H. Castera for preparing the pollen and dinocyst samples.

The authors thank J.P. Peypouquet and J. Villanue- 
va for critical reading of the manuscript and $G$. Clavero for improving the English text.

This paper is Bordeaux 1 University, DGO, UMR CNRS 5805 contribution nr. 1299.

\section{References}

Aaby, B. \& Tauber, H., 1995. Eemian and pollen. Nature 376: 2728.

Adkins, J.F., Boyle, E.A., Keigwin, L., \& Cortijo, E., 1997. Variability of the North Atlantic thermohaline circulation during the last interglacial period. Nature 390: 154-156.

Alley, R., 1995. Comparison of deep ice cores. Nature 373: 393.

Bassinot, F. \& Labeyrie, L., 1996. IMAGES MD 101. Institut Français pour la Recherche et la Technologie Polaires (Plouzané): $217 \mathrm{pp}$.

Berger, A. \& Loutre, M.F., 1991. Insolation values for the climate of the last 10 million years. Quaternary Science Reviews 10: 297-317.

Birks, H.J.B. \& Birks, H.H., 1980. Quaternary palaeoecology. Edward Arnold (London): 289 pp.

Blanco Castro, E., Casado González, M.A., Costa Tenorio, M., Escribano Bombín, R., García Antón, M., Génova Fuster, M., Gómez Manzaneque, F., Moreno Sáiz, J.C., Morla Juaristi, C., Regato Pajares, P. \& Sáiz Ollero, H., 1997. Los bosques ibéricos. Planeta (Barcelona): $572 \mathrm{pp}$.

Broecker, W.S., 1998. The end of the present interglacial: how and when? Quaternary Science Reviews 17: 689-694.

Cayre, O., 1997. Reconstitutions paléocéanographiques au Quaternaire récent à partir de l'analyse quantitative des foraminifères planctoniques dans l'océan Indien et dans l'Atlantique Nord Est. Ph.D. Université Aix-Marseille: 199 pp.

Cheddadi, R. \& Rossignol-Strick, M., 1995. Eastern Mediterranean Quaternary paleoclimates from pollen and isotope records of marine cores in the Nile Cone area. Paleoceanography 10: 291-306.

Cheddadi, R., Mamakova, K., Guiot, J., De Beaulieu, J.-L., Reille, M., Andrieu, V., Granoszewski, W. \& Peyron, O., 1998. Was the climate of the Eemian stable? A quantitative climate reconstruction from seven European pollen records. Palaeogeography Palaeoclimatology Palaeoecology 143: 73-85.

Cortijo, E., Duplessy, J.-C., Labeyrie, L., Leclaire, H., Duprat, J. \& Van Weering, T.C.E., 1994. Eemian cooling in the Norwegian Sea and North Atlantic Ocean preceding continental ice-sheet growth. Nature 372: 446-449.

Dansgaard, W., Johnsen, S.J., Clausen, H.B., Dahl-Jensen, D., Gundestrup, N.S., Hammer, C.U., Hvidberg, C.S., Steffensen, J.P., Sveinbjörnsdottir, A.E., Jouzel, J. \& Bond, G., 1993. Evidence for general instability of past climate from a $250-\mathrm{kyr}$ icecore record. Nature 364: 218-220.

De Beaulieu, J.-L. \& Reille, M., 1984: A long Upper Pleistocene pollen record from Les Echets, near Lyon, France. Boreas 13: 111-132.

De Beaulieu, J.-L. \& Reille, M., 1992. The last climatic cycle at La Grande Pile (Vosges, France). A new pollen profile. Quaternary Science Reviews 11: 431-438.

De Vernal, A., Londeix, L., Mudie, P.J., Harland, R., Morzadec-Kerfourn, M.-T., Turon, J.L. \& Wrenn, J.H., 1992. Quaternary organic-walled dinoflagellate cysts of the North Atlantic Ocean and adjacent seas : ecostratigraphy and biostratigraphy. In: Head, M.J. \& Wrenn, J.H. (eds.): Neogene and Quaternary dinoflagellate cyst of the North Atlantic Ocean and adjacent seas: ecostratigraphy and biostratigraphy. AASP Foundation (Dallas): 289-328.
De Vernal, A., Henry, M. \& Bilodeau, G., 1996. Techniques de préparation et d'analyse en micropaléontologie. Les cahiers du GEOTOP 3: 16-27.

Field, M.H., Huntley, B. \& Müller, H., 1994. Eemian climate fluctuations observed in a European pollen record. Nature 383: 806810.

Fiúza, A.F. de G., Macedo, M.E. d. \& Guerreiro, M.R., 1982. Climatological space and time variation of the Portuguese coastal upwelling. Oceanologica Acta 5: 31-40.

Follieri, M., Magri, D. \& Sadori, L., 1988. 250.000-year pollen record from valle di Castiglione (Roma). Pollen et Spores 30: 329-356.

Fronval, T. \& Jansen, E., 1997. Eemian and early Weichselian (140$60 \mathrm{ka})$ paleoceanography and paleoclimate in the Nordic seas with comparisons to Holocene conditions. Paleoceanography 12: 443-462.

Fronval, T., Jansen, E., Haflidason, H. \& Sejrup, P., 1998. Variability in surface and deep water conditions in the Nordic seas during the Last Interglacial period. Quaternary Science Reviews 17: 963-985.

GRIP members, 1993. Climate instability during the last interglacial period recorded in the GRIP ice core. Nature 364: 203-207.

Guiot, J., Pons, A., De Beaulieu, J.L. \& Reille, M., 1989. A 140.000 years continental climate reconstruction from two European pollen records. Nature 338: 309-313.

Heusser, L., 1985. Quaternary palynology of marine sediments in the northeast Pacific, northwest Atlantic, and Gulf of Mexico. In: Pollen records of Late-Quaternary North American sediments. AASP Foundation (Dallas): 385-403.

Heusser, L.E. \& Balsam, W.L., 1977. Pollen distribution in the N.E. Pacific ocean. Quaternary Research 7: 45-62.

Hooghiemstra, H., Stalling, H., Agwu, C.O.C. \& Dupont, L.M., 1992. Vegetational and climatic changes at the northern fringe of the Sahara 250,000-5000 years BP: evidence from 4 marine pollen records located between Portugal and the Canary Islands. Review of Palaeobotany and Palynolology 74: 1-53.

Kukla, G., McManus, J.F., Rousseau, D.-D. \& Chuine, I., 1997. How long and how stable was the last interglacial? Quaternary Science Reviews 16: 605-612.

Lentin, J.K. \& Williams, G.L., 1989. Fossil dinoflagellates: index to genera and species. AASP Foundation (Dallas) 20:473 pp.

Lézine, A.-M. \& Denèfle, M., 1997. Enhanced anticyclonic circulation in the eastern North Atlantic during cold intervals of the last deglaciation inferred from deep-sea pollen records. Geology 25: 119-122.

Litt, T., Junge, F.W. \& Böttger, T., 1996. Climate during the Eemian in north-central Europe - a critical review of the palaeobotanical and stable isotope data from central Germany. Vegetation History and Archaeobotany 5: 247-256.

Martinson, D.G., Pisias, N.G., Hays, J.D., Imbrie, J., Moore, T.C. \& Shackleton, N.J., 1987. Age dating and orbital theory of the ice ages: Development of a high-resolution 0 to 300,000-year chronostratigraphy. Quaternary Research 27: 1-29.

Maslin, M. \& Tzedakis, P.C., 1996. Sultry Last Interglacial gets sudden chill. Eos 77: 353-354.

Maslin, M., Sarnthein, M., Knaack, J.J., Grootes, P. \& Tzedakis, C., 1998. Intra-interglacial cold events: an Eemian-Holocene comparison. In: Cramp, A., MacLeod, C.J., Lee, S.V. \& Jones, E.J.W. (eds.): Geological evolution of ocean basins: results from the Ocean Drilling Program. Geological Society Special Publications (London) 131: 91-99.

Oppo, D.W., Horowitz, M. \& Lehman, S.J., 1997. Marine core evidence for reduced deep water production during Termination II followed by a relatively stable substage $5 \mathrm{e}$ (Eemian). Paleoceanography 12: 51-63. 
Pagney, P., 1976. Les climats de la Terre. Masson (Paris): 150 pp.

Peinado Lorca, M. \& Martínez-Parras, J.M., 1987. Castilla-La Mancha. In: Peinado Lorca, M. \& Rivas Martinez, S. (eds.): La vegetación de España. Universidad de Alcalá de Henares (Alcala de Henares): 163-196.

Pons, A., Guiot, J.L., De Beaulieu, J.L. \& Reille, M., 1992. Recent contribution to the climatology of the last glacial-interglacial cycle based on french pollen sequences. Quaternary Science Reviews 11:439-448.

Pons, A. \& Reille, M., 1988. The Holocene-and Upper Pleistocene pollen record from Padul (Granada, Spain): a new study. Palaeogeography Palaeoclimatology Palaeoecology 66: 243-263.

Sánchez Goñi, M.F., Eynaud, F., Turon, J.-L. \& Shackleton, N.J., 1999. High resolution palynological record off the Iberian margin: direct land-sea correlation for the Last Interglacial complex. Earth and Planetary Science Letters 171: 123-137.

Sarnthein, M. \& Tiedemann, R., 1990. Younger dryas-style cooling events at glacial termination I-VI at ODP Site 658: associated benthic D13C anomalies constrain meltwater hypothesis. Paleoceanography 5: 1041-1055.

Seidenkrantz, M.-S., 1993. Benthic foraminiferal and stable isotope evidence for a Younger Dryas style cold spell at the SaalianEemian transition, Denmark. Palaeogeography Palaeoclimatology Palaeoecology 102: 103-120.

Seidenkrantz, M.-S. \& Knudsen, K.L., 1997. Eemian climate and hydrographical instability on a marine shelf in Northern Denmark. Quaternary Research 47: 218-234.

Thouveny, N., De Beaulieu, J.L., Bonifay, E., Creer, K.M., Guiot,
J., Icole, M., Johnsen, S., Jouzel, J., Reille, M., Williams, T. \& Williamson, D., 1994. Climate variations in Europe over the past $140 \mathrm{kyr}$ deduced from rock magnetism. Nature 372: 503-506.

Turon, J.-L., 1984a. Direct land/sea correlations in the last interglacial complex. Nature 309: 673-676.

Turon, J.-L., 1984b. Le palynoplancton dans l'environnement actuel de l'Atlantique nord-oriental. Evolution climatique et hydrologique depuis le dernier maximum glaciaire. Université de Bordeaux I (Bordeaux): 313 pp.

Turon, J.L., Lecoeur, L., de Vernal, A., Rochon, A. \& Lézine, A.M., 1995. Fonction de transfert dinokystes: evolution des conditions de surface en Atlantique Nord-oriental depuis le dernier maxi-

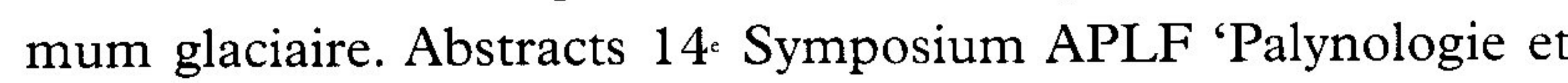
Changements Globaux' (Paris):103.

Tzedakis, P.C., Bennett, K.D.\& Magri, D., 1994. Climate and the pollen record. Nature 370: 513.

Weaver, A.J. \& Hughes, T.M.C., 1994. Rapid interglacial climate fluctuations driven by North Atlantic ocean circulation. Nature 367: 447-450.

Woillard, G.M., 1978. Grande Pile peat bog: a continuous pollen record for the last 140.000 years. Quaternary Research 9: 1-21.

Woillard, G. \& Mook, W.G., 1982. Carbon-14 dates at Grande Pile: correlation of land and sea chronologies. Science 215:159-161.

Zagwijn, W.H., 1961. Vegetation, climate and radiocarbon datings in the Late Pleistocene of the Netherlands. Mededelingen Geologische Stichting Nieuwe Serie 14: 15-45.

Zagwijn, W.H., 1996. An analysis of Eemian climate in western and central Europe. Quaternary Science Reviews 15: 451-469. 